\title{
IMMUNOCYTOLOGY IN ARTHRITIC JOINTS
}

\author{
BY \\ MARION I. BARNHART*, JEANNE M. RIDDLE, AND G. B. BLUHM \\ Wayne State University School of Medicine, Department of Physiology and Pharmacology, \\ and the Henry Ford Hospital, Department of Pathology and Division of Rheumatology, Detroit, Michigan
}

The capacity of exudative neutrophils to phagocytose and digest fibrin, an important constituent of inflammatory exudates, was investigated in various types of arthritis. In addition, the catheptic enzyme content of inflammatory cells was established directly with the aid of fluorescent anticathepsin. The intracellular organization of cathepsin varied considerably among the patients. The distribution can be related to intracellular digestion of phagocytosed proteins and to release of cathepsin for extracellular proteolysis.

From previous studies in dogs, we knew that exudative neutrophils exercise their phagocytic capacity to ingest and digest autologous fibrin during an experimental acute inflammation. Fibrin or something derived from it appeared to be a specific attractant for polymorphonuclear leucocytes. Furthermore, the continued addition of fibrin to the inflammatory site delayed the mononuclear cell entry that is so prominent in later stages of inflammation (Riddle and Barnhart, 1964). We wondered if a similar interrelationship between fibrin deposits and granulocytes might not exist within acute inflammatory sites in man. Joint disease offered an excellent source of inflammatory exudates to represent various stages of inflammation. The extent to which phagocytosis of fibrin occurred and the significance of its intracellular digestion as compared to the phagocytosis of other protein aggregates is the subject of this communication.

Immunocytology identified the protein constituents of exudative leucocytes. With fluorescent markers specific for either fibrin, rheumatoid factor (IgM), gamma globulin (IgG), or albumin, we found that these substances were handled in different ways by exudative neutrophils from various arthritic patients. The significance of neutrophilic phagocytosis of fibrin and the role of fibrin per se in accounting for the persistence and recycling of acute inflammation becomes apparent from our work.

\section{Material and Methods}

\section{Classification of Patients}

Synovial fluids from forty patients with joint disease were studied after classification according to the diagnostic criteria of the American Rheumatism Association. Of these patients, 21 had rheumatoid arthritis (RA), three had ankylosing spondylitis, four had psoratic arthritis, four had gout or pseudogout, and four had degenerative joint disease. There was one patient each with Reiter's syndrome, regional ileitis with joint involvement, allergic arthritis, and traumatic arthritis.

\section{Processing of Synovial Fluid}

Synovial fluid was aspirated from the involved joint (usually a knee) of selected patients, managed by the Division of Rheumatology at Henry Ford Hospital. A few patients provided several effusions from a single joint during the study period. The aspirates were immediately anticoagulated with 3.8 per cent. sodium citrate (1 part citrate to 9 parts of synovial fluid). After thorough mixing, the sample was centrifuged for 10 minutes at 1,000 r.p.m. in an International Table Model centrifuge. The supernatant was saved for biochemical assays. The sediment contained exudative leucocytes and large particulates of the exudate. Smears were made for fluorescent as well as conventional microscopy.

\section{Immunofluorescent Markers}

Purified human plasma proteins were given in microgram quantities with $\mathrm{Al}(\mathrm{OH})_{3}$ to induce antibody formation in rabbits (Barnhart, Anderson, and Baker 1962). Fibrinogen (97 per cent. clottable) was prepared by ethanol fractionation and purified further by tannic acid treatment (Barnhart and Forman, 1964). Such products were homogeneous by immuno-electrophoresis with univalent antifibrinogen and multivalent antiplasma. The rheumatoid factor (IgM) and gamma globulin (IgG) were prepared by Dr. Lospalluto, according to published procedure (Lospalluto and Ziff, 1959), from the plasma of a patient with classical RA and a differential rheumatoid agglutination titre of $1: 2,560$.

*Aided by research grant HE 04712 from the National Heart Institute, USPHS. 
Neither of these proteins, when tested for purity by immuno-electrophoresis, reacted with antifibrinogen. Also, another IgG product (Pentex, Inc.) was used as antigen. The IgM was a poor antigen but the weak antisera evoked were concentrated to provide acceptable reagents for cytology. Albumin ( 2 or 3 times crystallized, Pentex, Inc.) was used to elicit anti-albumin.

A cathepsin concentrate rich in cathepsin $\mathrm{D}$ and $\mathrm{E}$ activities was prepared from human spleen (Barnhart, Quintana, Lenon, Bluhm, and Riddle, 1967). Anticathepsin was produced by injecting rabbits with an $\mathrm{Al}(\mathrm{OH})_{3}$ mixture containing $1 \mathrm{mg}$. cathepsin $/ \mathrm{kg}$. body weight. The resultant antisera were checked for reaction with the original cathepsin concentrate in agar gel diffusion systems. The antisera were multicomponent. To identify the minor components, immunological testing was done with plasma and purified plasma proteins. Both antialbumin and antifibrinogen were identified. It was necessary to adsorb the anticathepsin with human plasma to remove the undesired antibodies for plasma proteins. The adsorbed anticathepsin did not react when checked for immunological reactivity with plasma or purified albumin, fibrinogen, or gamma globulin. However, it contained anticathepsin because it inhibited the albuminolytic power of the cathepsin concentrate used to induce antibody formation.

The potency of the antisera prepared for this study appears in Table I. Antisera were never pooled, since there was considerable advantage in exploiting the uniqueness of certain of these immunological tools for studies of cell function.

The strongest and most selective of these antisera (Table II) were chosen to prepare the fluorescent markers for immunocytology. Gamma globulin concentrates were prepared from the individual antisera by ethodin and ethanol fractionation. These products were more
TABLE I

POTENCY OF ANTISERA

\begin{tabular}{l|c|c|c}
\hline Product & $\begin{array}{c}\text { Rabbits } \\
\text { Injected }\end{array}$ & $\begin{array}{c}\text { Dose } \\
\text { (mg./kg. body weight) }\end{array}$ & $\begin{array}{c}\text { Precipitin Titre } \\
\text { (reciprocal of } \\
\text { dilution)* }\end{array}$ \\
\hline Albumin .. & 11 & $0 \cdot 1-1 \cdot 0$ & $4096-16384$ \\
Cathepsin.. & 16 & $0 \cdot 1-8 \cdot 3$ & $64-2048$ \\
Fibrinogen & 30 & $0 \cdot 1-1 \cdot 0$ & $1024-16384$ \\
IgG.. & 3 & $0 \cdot 01-1 \cdot 0$ & 4096 \\
IgM $\quad .$. & 9 & $0 \cdot 05-2 \cdot 0$ & $8-16$ \\
\hline
\end{tabular}

*Stock, 1 per cent. purified protein used for immunization, diluted as indicated.

than 98 per cent. gamma globulin and were complexed according to published procedures (Anderson and Barnhart, 1964) with either rhodamine sulphonyl chloride (RSC) prepared from lissamine rhodamine B 200 (I.C.I., England, courtesy of I.C.I. Organics Inc., Providence, R.I.) or fluorescein isothiocyanate (FITC) (Baltimore Biological Laboratory, Baltimore, Md.). The fluorescent reagents were frozen and stored at $-20^{\circ} \mathrm{C}$.

\section{Fluorochroming Procedures}

A dilute fluorescent antibody was used with careful control of the dye concentration of the protein conjugate. After thawing, the fluorescent antibody was diluted with physiological saline so that by spectrophotometry the optical density was near $\mathbf{0 \cdot 2 0}$. The adjustment for RSC antibodies was made at $560 \mu$; while the spectrophotometer was set at $480 \mu$ for adjusting the FITC antibodies. Such a fluorescent antibody was applied for $\mathbf{4 0}$ minutes to the smears of concentrated leucocytes which were fixed previously in Wolman-Behar fixative (Wolman and Behar, 1952) for 10 minutes at $-20^{\circ} \mathrm{C}$. To minimize autofluorescence, smears were fixed within 18 to 24 hours of aspiration. The fluorochromed slides were rinsed well

TABLE II

IMMUNOLOGICAL REACTIVITY OF SELECTED ANTISERA ASSESSED BY IMMUNODIFFUSION AND IMMUNO-ELECTROPHORESIS

\begin{tabular}{|c|c|c|c|c|c|c|c|c|}
\hline \multicolumn{2}{|l|}{ Antisera } & \multicolumn{5}{|c|}{ Number of Precipitin Bands Formed by Interaction with: } & \multirow[b]{2}{*}{ IgG } & \multirow[b]{2}{*}{ IgM } \\
\hline Identification & Titre* & Plasma & Serum & Albumin & Cathepsin & Fibrinogen & & \\
\hline Antialbumin & $\begin{array}{r}4096 \\
16384\end{array}$ & $\begin{array}{l}1 \\
1\end{array}$ & $\begin{array}{l}1 \\
1\end{array}$ & $\begin{array}{l}1 \\
1\end{array}$ & & $\begin{array}{l}\mathbf{0} \\
\mathbf{0}\end{array}$ & $\begin{array}{l}\mathbf{0} \\
\mathbf{0}\end{array}$ & $\begin{array}{l}\mathbf{0} \\
\mathbf{0}\end{array}$ \\
\hline Anticathepsin & $\begin{array}{r}256 \\
2048\end{array}$ & $\begin{array}{l}0 \\
0\end{array}$ & & $\begin{array}{l}0 \\
0\end{array}$ & $\begin{array}{l}2-3 \\
1-2\end{array}$ & $\begin{array}{l}0 \\
0\end{array}$ & $\begin{array}{l}\mathbf{0} \\
\mathbf{0}\end{array}$ & \\
\hline $\begin{array}{lr}\text { Antifibrinogen } & \\
& 75 \\
250 \\
307\end{array}$ & $\begin{array}{l}1024 \\
4096 \\
4096\end{array}$ & $\begin{array}{l}1 \\
1 \\
1\end{array}$ & $\begin{array}{l}\mathbf{0} \\
\mathbf{0} \\
\mathbf{0}\end{array}$ & $\begin{array}{l}\mathbf{0} \\
\mathbf{0} \\
\mathbf{0}\end{array}$ & & $\begin{array}{l}1 \\
1 \\
1\end{array}$ & $\begin{array}{l}\mathbf{0} \\
\mathbf{0} \\
\mathbf{0}\end{array}$ & $\begin{array}{l}\mathbf{0} \\
\mathbf{0} \\
\mathbf{0}\end{array}$ \\
\hline Anti-IgG & 4096 & 1 & 1 & 0 & 0 & 0 & 1 & $\mathbf{0}$ \\
\hline Anti-IgM & $\begin{array}{r}8 \\
16\end{array}$ & $\begin{array}{l}1 \\
1\end{array}$ & $\begin{array}{l}1 \\
1\end{array}$ & $\begin{array}{l}\mathbf{0} \\
\mathbf{0}\end{array}$ & $\begin{array}{l}\mathbf{0} \\
\mathbf{0}\end{array}$ & $\begin{array}{l}\mathbf{0} \\
\mathbf{0}\end{array}$ & $\begin{array}{l}\mathbf{0} \\
\mathbf{0}\end{array}$ & $\begin{array}{l}1 \\
1\end{array}$ \\
\hline
\end{tabular}

* Expressed as reciprocal of dilution of 1 per cent. protein antigen.

†Adsorbed with plasma to remuve antibodies for fibrinogen and albumin. 
in tap water to remove fluorescent material not specifically attracted to cells containing the antigen or an immunological relative.

A number of controls were run concurrently on each leucocyte smear. One area of cells was treated with unlabelled antiserum to provide an evaluation of the autofluorescence of the cell population. Blocking reactions and adsorbed fluorescent antibodies were used on other areas of the smear to establish the specificity of the leucocyte staining. For example, treatment of a smear with unlabelled antifibrinogen serum completely suppressed cell staining with fluorescent antifibrinogen, although some of these cells remained competent to fix either fluorescent anti-IgM or fluorescent anti-IgG. One adsorption experiment that established specificity of cell staining was treatment of a fluorescent antibody with the purified protein originally used to induce antibody formation; i.e. fluorescent anti-IgG adsorbed with purified IgG. A similar adsorption with the proper protein was applied to each fluorescent antibody used in the cell work. Comparison of the staining capacity of an adsorbed fluorescent antibody with its unadsorbed fluorescent antibody of similar optical density illustrated the reduced staining capacity of the adsorbed antibody. Various combinations of controls were employed to reach the conclusion that there were no cross-reactions between these fluorescent cell markers (antifibrinogen, anti-IgM, anti-IgG, antialbumin, or anticathepsin). Clearly, a leucocyte stained with one of the fluorescent reagents was reflecting its content of the protein used to elicit that antibody or reflected the presence of molecules immunologically related to the original antigen.

By use of red (RSC) and green (FITC) fluorescent markers on the same smear it was possible to identify and study the distribution of at least two different proteins within a single cell. In favourable situations the complex nature of the phagocytosed material was indicated by the attraction of both the red and green markers to the same site and a yellow reaction occurred. This implied the presence of two different proteins in the same phagocytic vacuole. In this report, the green antibody was FITC antifibrinogen. The red antibody was either RSC anti-IgM, or anti-IgG, or anticathepsin.

\section{Fluorescent Microscopy and Photography}

A Zeiss photomicroscope equipped with fluorescent accessories and the Ultra $Z$ dark-field condensor was used. An Osram HBO 200 was the light source. Ultraviolet and blue light were passed by a BG 12 exciter filter and activated the fluorescent compound. Barrier filters $O G 4$ and $O G 5$ proved most useful for viewing, although filters passing light from 470 to $550 \mu$ were also satisfactory. When both RSC antibody and FITC antibody were employed in a double tagging procedure, the colours were especially prominent with the OG 4 or filters with wave lengths from 470 to $515 \mu$.

Black and white photographs employed Eastman Tri-X film and exposures of 1 to 2 minutes with forced development. Colour work was successful with either
Eastman High Speed Ektachrome (daylight) or Super Anscochrome 200 (daylight). Exposures of 2 to 4 minutes required special development. Exposures of 5 to 10 minutes, with regular commercial development, often gave the best colour but vibrations and fluorescent quenching can eliminate the advantages of longer exposures.

\section{Cell Viability}

The viability of the exudative leucocytes in synovial fluids was assessed by a neutral red procedure (Wintrobe, 1961). Leucocytes were accepted as viable if they excluded neutral red from their nuclei. The viable leucocytes in these preparations ranged from 80 to 100 per cent. with the majority above 90 per cent.

\section{Results}

The immunochemical heterogeneity of the cytoplasmic contents of exudative leucocytes was revealed by application of fluorescent antibodies. Also, information was gained on the immunochemical composition of extracellular particulates present in some synovial fluids.

\section{Distribution of Fibrin-Related Material}

Fluorescent antifibrinogen was placed on smears containing the concentrated leucocytes and other sedimentable substances obtained from the synovial fluid aspirates of patients with inflammatory joint disease. The fluorescent reagent was specific for fibrinogen, fibrin, or their breakdown products, since these molecules are all immunological relatives. Substances that reacted with this fluorescent marker were prominent in neutrophils, occasionally present in mononuclear cells, and frequently seen as extracellular particulates.

(1) Neutrophils.-Most of the patients showed some exudative neutrophils with a cellular localization of material that attracted the fluorescent antifibrinogen. Peripheral blood smears from these patients and normal individuals did not react with this fluorescent antibody. Thus, it seemed likely that the stained exudative neutrophils had ingested either fibrin or fibrin breakdown products formed in the synovial fluid.

The magnitude and intensity of the neutrophil staining varied with different patients and also in neutrophil populations aspirated from two different joints of the same patient. Neutrophils from the majority of the fluids (71 per cent.) presented distinct cytoplasmic fluorescence which varied in colour from pale orange to red. Seven neutrophil populations (20 per cent.) showed a minimal fluorescent reaction and three other leucocyte preparations of the 35 
studied were completely nonreactive with RSC antifibrinogen. Thus, there was staining variation from neutrophil to neutrophil within a single leucocyte population (Fig. 1). Different numbers of neutrophils appeared to be engaged in fibrin phagocytosis and intracellular digestion in various patients. In those exudates which contained neutrophils which were nonreactive with fluorescent antifibrinogen, either fibrin phagocytosis was not proceeding or fibrin digestion and removal was complete at the time of aspiration and study. In contrast, over 90 per cent. of the exudative neutrophils from one RA patient and one patient with gout fluoresced brilliantly in response to RSC antifibrinogen (Fig. 2, opposite).
There were two distinct patterns or distributions of the material which reacted with fluorescent antifibrinogen. Diffuse or fine granular cytoplasmic staining was typical of neutrophils from patients with reactive cells (Fig. 2). Gross inclusion masses were especially noted in the RA group (Fig. 3, overleaf).

Five of seventeen patients ( 8 of 21 samples) showed brightly fluorescent intracellular masses containing fibrin-related molecules. These inclusion bodies varied in size and fluorescent intensity. Neutrophils with these inclusion bodies of fibrin-related material frequently showed the diffuse type of staining. Some neutrophils with stained inclusions contained other masses that did not react with fluorescent antifibrinogen. Still other neutrophils

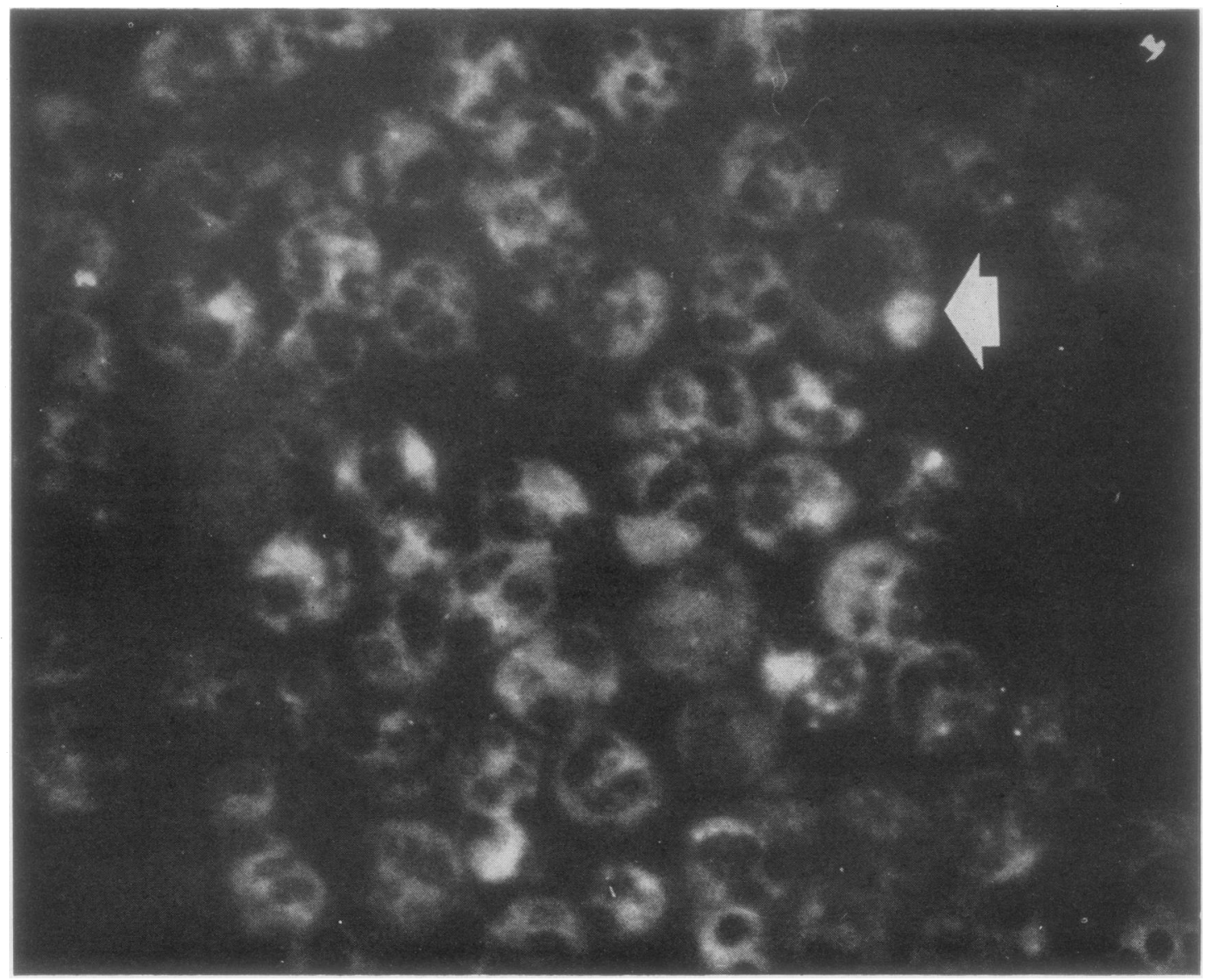

Fig. 1.-Synovial fluid leucocytes from a patient with rheumatoid arthritis after exposure to fluorescent antifibrinogen. Note variations among neutrophils that contain cytoplasmic material immunologically related to fibrin. Both diffuse and mass types of fluorescence (white) are present. A rare mononuclear leucocyte (arrow) has phagocytosed a neutrophil remnant which was fiuorescent. $\times 1,200$. 


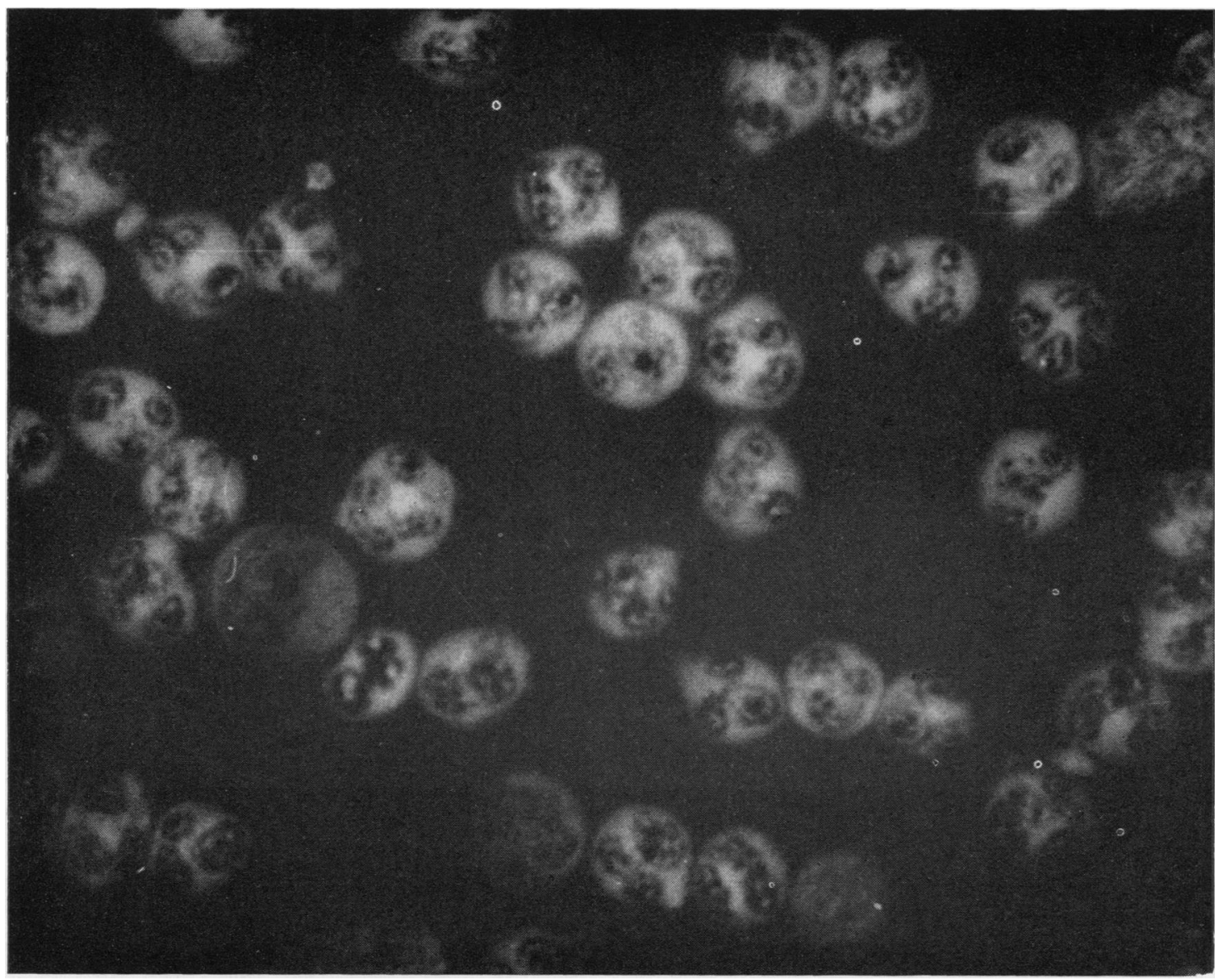

Fig. 2.-Neutrophils from a patient with gout reacted with fluorescent antifibrinogen. Observe the diffuse type of cytoplasmic fluorescence (white) which represents ingested fibrin. Several mononuclear leucocytes in contrast show grey cytoplasms. $\times 1,280$.

contained numerous stained inclusions without any obvious fine granular cytoplasmic staining. It was interesting that the patients who presented gross inclusions of fibrin related material also had rheumatoid nodules.

(2) Extracellular Strands and Masses.-The majority of exudates had extracellular particulates or threads that reacted brilliantly with RSC antifibrinogen. In the group with rheumatoid arthritis, ten of seventeen patients (13 of 21 separate aspirates) showed flakes, strands, or masses that either were composed of fibrin-related molecules or were coated with such material. Similarly, in the group with ankylosing spondylitis, four of six aspirates taken from four patients showed extracellular fibrin related substances.
(3) Mononuclear Cells.-Although mononuclear cells were not the predominant cell population in these patients, their cell chemistry was visible with the fluorescent markers. Large mononuclears (macrophages and hypertrophied lymphocytes) generally did not react with fluorescent antifibrinogen (Fig. 2). An occasional mononuclear contained obvious neutrophilic cytoplasmic buds which fluoresced brightly to indicate fibrin-related material originally present in the neutrophil or simply to illustrate increased autofluorescence of cell remnants (Fig. 1). About 20 per cent. of the patients showed a faint diffuse fluorescence in a small number of the medium-sized mononuclears (plasma cells and/or lymphocytes). Neither macrophages nor small lymphocytes nor monocytes contained enough fibrinrelated material for detection with fluorescent antifibrinogen. The most intense mononuclear res- 


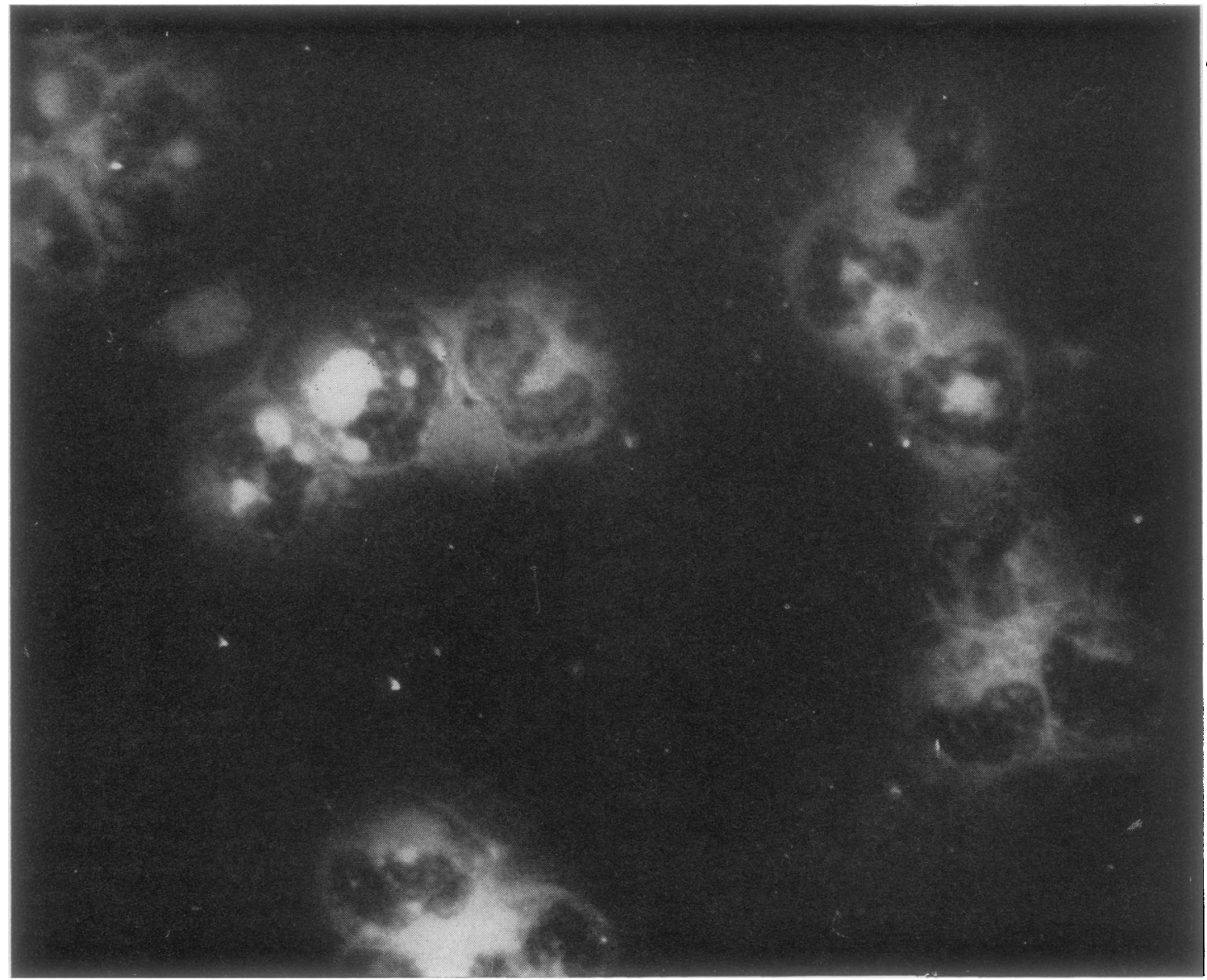

Fig. 3. Synovial fiuid neutrophils from patients with rheumatoid arthritis frequently show prominent phagosomes (white) that react with fluorescent antifibrinogen. The grey cytoplasmic response in several neutrophils and the centrally located mononuclear reflects autofluorescence. $\times 1,280$.

ponse (1 to $2+$ ) occurred in patients with osteoarthritis. None of the patients studied in this series exhibited a mononuclear fluorescent intensity that approached the spectacular brilliance (graded as $4+$ ) observed in the neutrophils.

\section{Distribution of IgM}

From our RA patient series 78 per cent. had neutrophils which reacted with fluorescent antiIgM. Although the number of neutrophils concerned and their intensity of fluorescence varied, two patterns of staining were obvious. Neutrophil inclusion bodies were observed in 50 per cent. of the aspirates(Fig. 4, opposite). Also, most of these aspirates had neutrophils that exhibited a diffuse type of cytoplasmic staining. In 33 per cent. of the RA patients only diffuse type staining occurred. The remaining 22 per cent. of the RA series did not have leucocytes that contained enough IgM material to react with the fluorescent marker. Extracellular masses were present in most of the patients with rheumatoid arthritis and reacted brightly with fluorescent anti-IgM. Neutrophils taken from aspirates of other types of inflammatory joint disease did not fluoresce significantly with anti-IgM. An occasional neutrophil from two subjects with ankylosing spondylitis gave a \pm reaction, but inclusion bodies were not observed. Mononuclear cell fluorescence was not prominent in most of the patients studied, although a rare mononuclear (plasma cell) showed specific fluorescence which probably reflected the cellular site of synthesis for rheumatoid factor (Mellors, Nowoslawski, and Korngold, 1961). 


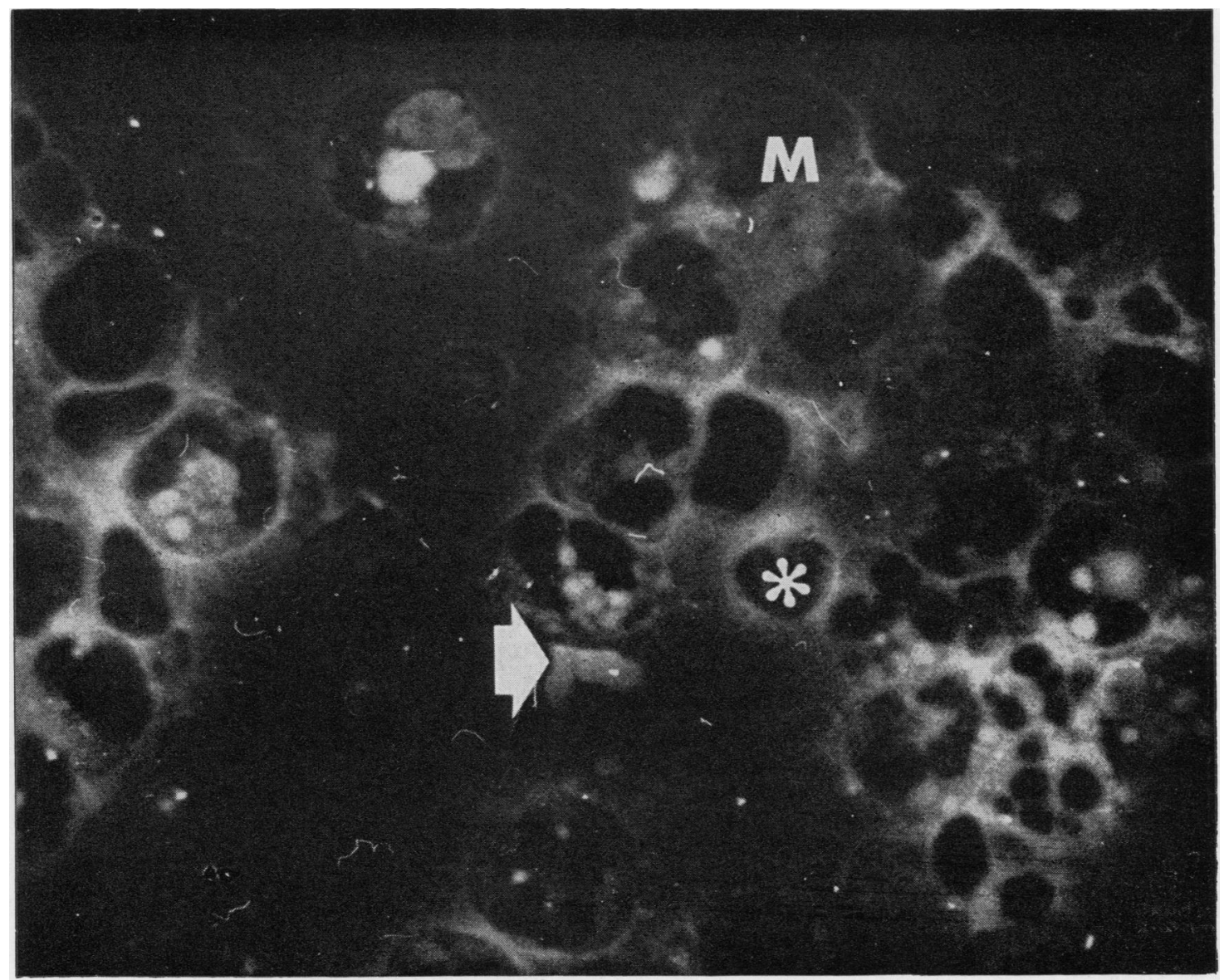

Fig. 4.-Distribution of IgM-related material in neutrophils from a patient with rheumatoid arthritis. Fluorescent anti-IgM (white) marked numerous neutrophil phagosomes and also reacted with extracellular masses (arrow). Large mononuclears (M) were usually nonreactive. An occasional plasma cell $(*)$ fluoresced, probably to indicate the cellular site of IgM synthesis. $\times 1,200$.

\section{Distribution of IgG}

The cellular localization of IgG was clearly shown by the fluorescence achieved when RSC anti-IgG was applied to cell preparations. In the RA series, 91 per cent. of the smears showed neutrophil fluorescence of the diffuse type with the majority of polymorphonuclears reactive (Fig. 5, overleaf). The intensity of specific cell fluorescence was usually less than that for cellular IgM or fibrin-related substances. 42 per cent. of these patients showed inclusion bodies that reacted brilliantly with the RSC anti-IgG. This reaction varied in the patient series from a rare cell to more than 50 per cent. of the polymorphonuclear population exhibiting fluorescent inclusion bodies. Generally the mononuclear cells did not contain enough IgG for detection with the fluorescent marker. The rare mononuclear which reacted stained diffusely, except for one patient with RA who showed inclusion bodies in a few medium-sized mononuclears. One RA patient of the twelve studied in this series had many plasma cells which fluoresced with an intensity that equalled that of the neutrophils. This specific fluorescence probably represented the cellular origin of IgG rather than phagocytosed material (Solomon, Fahey, and Malmgren, 1963). Extracellular staining was obvious in 75 per cent. of the patients, with 60 per cent. showing various sized aggregates of quite fluorescent amorphous material. Effusions from three non-rheumatoid subjects did not contain cells with a positive response to anti-IgG. 


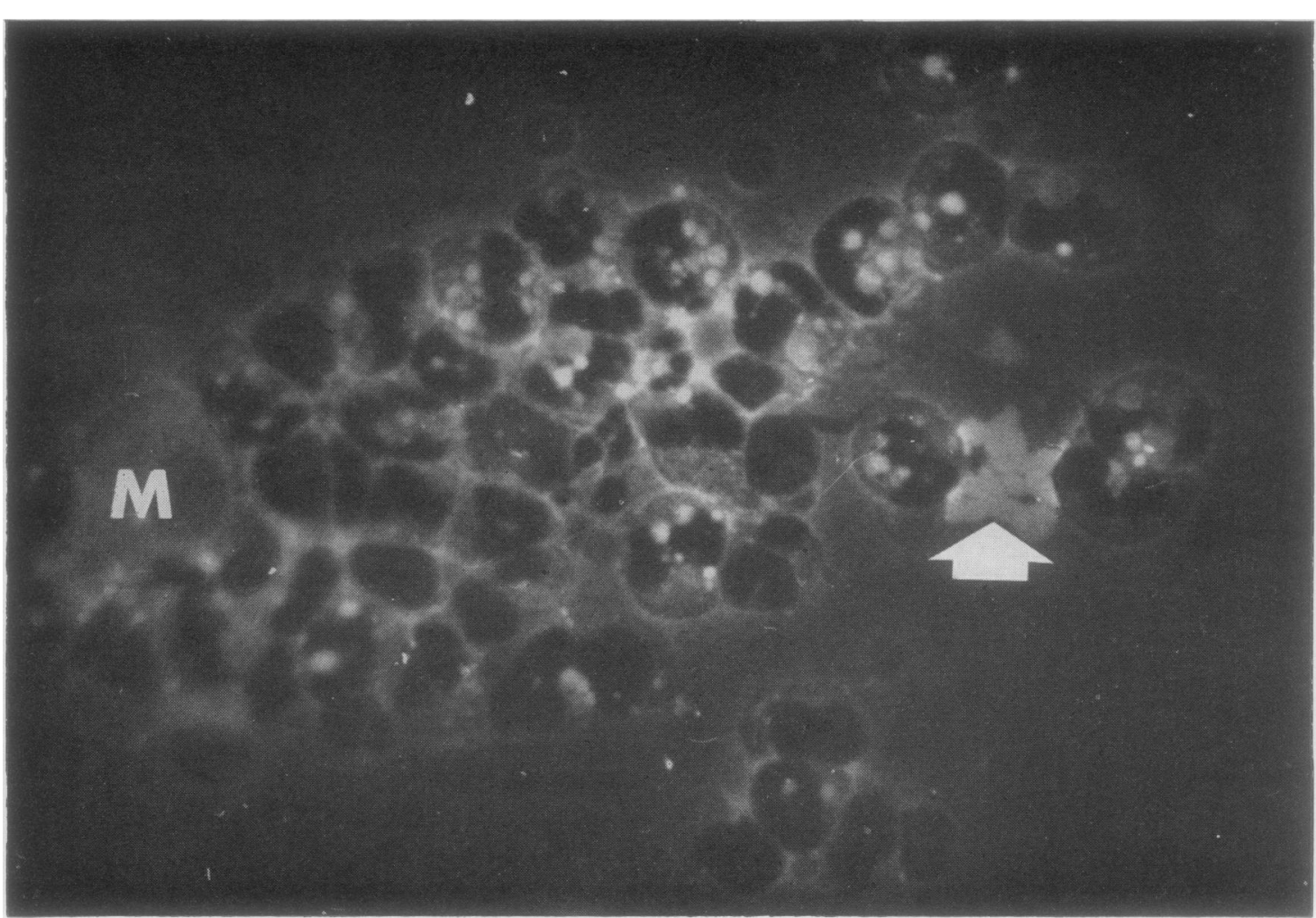

Fig. 5.-IgG material was especially noteworthy in phagosomes of neutrophils and as extracellular masses (arrow) in patients with rheumatoid arthritis. The large mononuclear $(\mathbf{M})$ shows only autofiuorescence (grey cytoplasm) with the small extracellular fluorescent granule. $\times 800$.

\section{Distribution of Albumin-related Substances}

Neutrophils again were the predominant cell responding to application of fluorescent antialbumin, with 90 per cent. of the patients positive. The reactivity of the neutrophils was not obviously related to the clinical classification of the patient. Patients with rheumatoid arthritis, ankylosing spondylitis, and gout showed cellular albumin. There was variation in specific fluorescence, which ranged from 1 to $4+$ and was finely granular, except for one RA patient who showed stained inclusion bodies of varying intensity. This subject also exhibited diffuse staining in many of the neutrophils (Fig. 6, opposite) as well as occasional autofluorescent masses that did not react with RSC antialbumin.

The intensity of the albumin reaction did not necessarily parallel the specific fluorescent responses to IgM or fibrin-related material in exudative cells of the same patient. Quite obviously, the phagocytosis and/or degree of intracellular digestion were proceeding at different rates for the various proteins under consideration. Except for two patients (both RA), the mononuclears were negative. In these two patients only a small number of mononuclears stained specificially and the uptake of albumin-related molecules could be graded $2+$ and $3+$; even so, it was less intense than the neutrophilic uptake. Extracellular albumin was visible in most preparations as fluorescent fine granular background material in which cells were embedded, or as fluorescent amorphous masses of varying size, or as distinct strands of fluorescent material. In the latter two instances, the intensity of specific fluorescence was graded $3+$. The fluorescent strands or fibres were probably mucin comprised of mucopolysaccharide complexed with albumin. Only a few synovial exudates showed the fibrous type of ștaining as a prominent feature.

\section{Distribution of Cathepsins}

Peripheral blood smears showing cellular cathepsins were conspicuous in the granulocytes. The granular fluorescence of both blood neutrophils and 


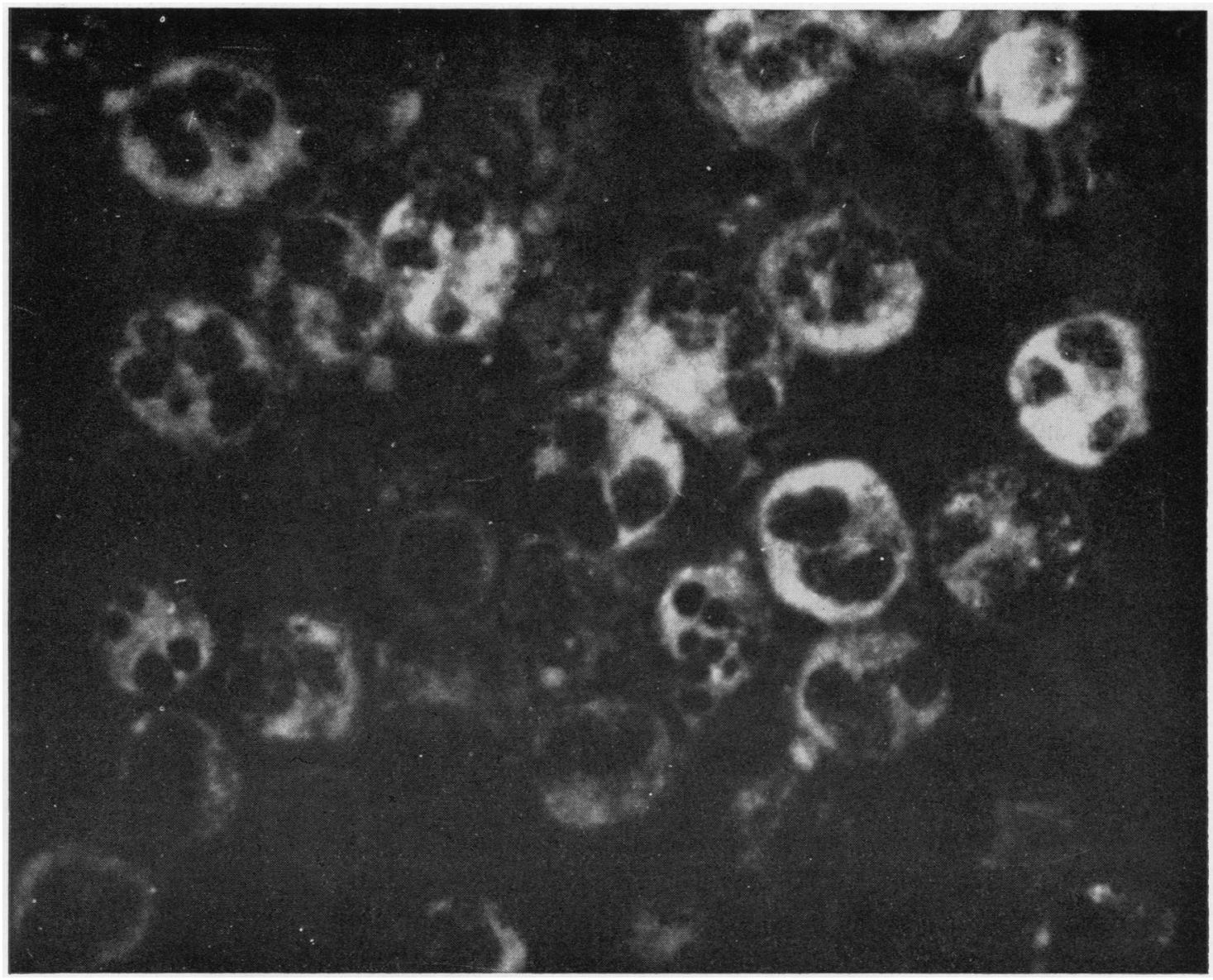

Fig. 6.-Cellular localizations of albumin-related material in neutrophils from a patient with rheumatoid arthritis reacted with fluorescent antialbumin (white). Note the great differences from cell to cell with both the diffuse and mass types of response featured. $\times 1,280$.

eosinophils corresponded to the specific granulations of these two cell types. Blood eosinophils fluoresced more intensely than the neutrophils. Neither erythrocytes nor mononuclear cells showed significant fluorescence with this specific reagent. Material that reasted with fluorescent anticathepsin was found both intracellularly and extracellularly in the synovial exudates.

Generally the exudative neutrophils showed a diffuse type of finely granular staining (Fig. 7, overleaf). In some patients, the cell staining was very hazy and homogeneous in appearance. Pyknotic neutrophils showed bright homogeneous staining on the order of $4+$. Identification of specific neutrophil or eosinophil granules as discrete bodies was difficult. It seemed likely that many granules had fused and that the cells had partially or totally degranulated. Several RA patients and two with gout had 50 to 70 per cent. of their neutrophils obviously degranulated. This reduced cell staining probably reflected the release of cellular cathepsin.

Redistribution of cellular cathepsin was prominent in several patients with RA. In these neutrophils the fluorescent cytoplasmic masses varied in size and were graded $2+$ to $4+$; one RA patient had 90 per cent. of the neutrophils in this condition. Occasionally the contribution of lysosomal cathepsin to the phagosomes was especially distinct because the coalesced cathepsin was all that remained in the digestive vacuole (Fig. 8, overleaf). Diffuse cytoplasmic staining was the exception in these patients and many neutrophils contained masses that were nonreactive with fluorescent anticathepsin.

Cellular cathepsin was not notable in the other cells types present in the synovial effusions. An occasional macrophage contained brightly fluorescent 


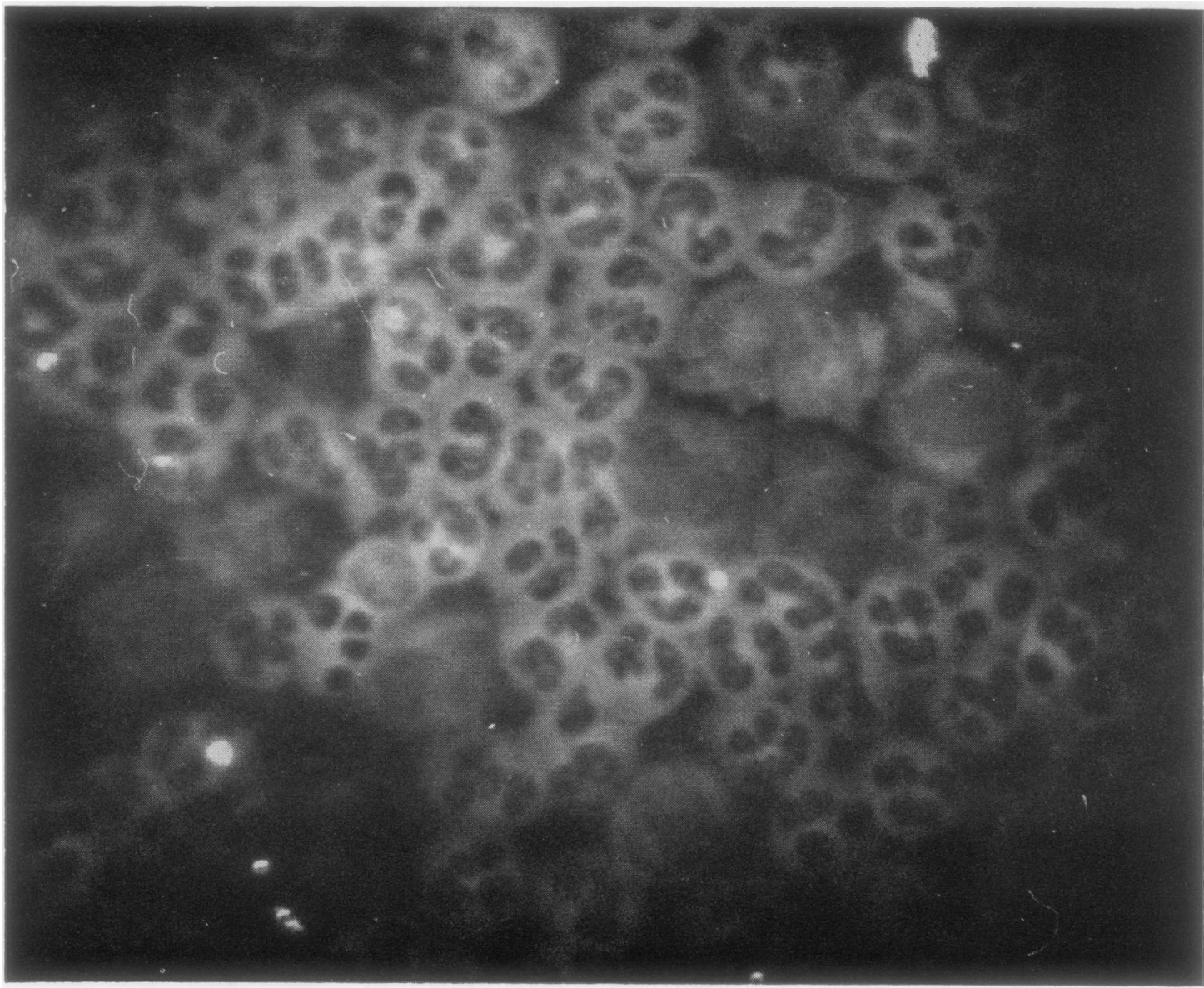

Fig. 7.-Synovial fluid leucocytes from a patient with monoarticular arthritis reacted with fluorescent anticathepsin. The greatest concentrations of cathepsin appeared in neutrophils as fine granular material. Mononuclears showed greyer cytoplasms similar in fluorescent intensity to autofiuorescence. $\times 1,280$.

buds or fragments of degenerating neutrophils. A small number of mononuclears showed cellular cathepsin as a faint fine orange dust graded as 1 to $2+$ when RSC anticathepsin was the stain.

Extracellular cathepsin was found as masses of various sizes, accumulated along strands of unstained material and distributed as a finely granular matrix. The intensity and variety of extracellular response varied considerably. Frequently, extracellular fluorescence was high when the polymorph neutrophil staining was weak.

\section{Double Staining with Contrasting Fluorescent Markers}

Neutrophils from RA joints frequently contained discrete phagosomes full of material. It was not unusual to observe individual neutrophils with two distinct groups of phagosomes; one type was identified by its interaction with a specific fluorescent antibody; the other type was nonreactive but easily visible by its autofluorescent properties. The contents of these autofluorescent phagosomes could not be identified with only a single fluorescent stain. A double-tag procedure employed a red antibody and a green antibody to show how an individual cell handled two different proteins. In some cases the aggregation of the two proteins within the same phagocytic vacuole was indicated by the mixing of red and green antibody to give the phagosome a distinct yellow colour.

Functional differences between neutrophils were striking even when obtained from the same joint. 


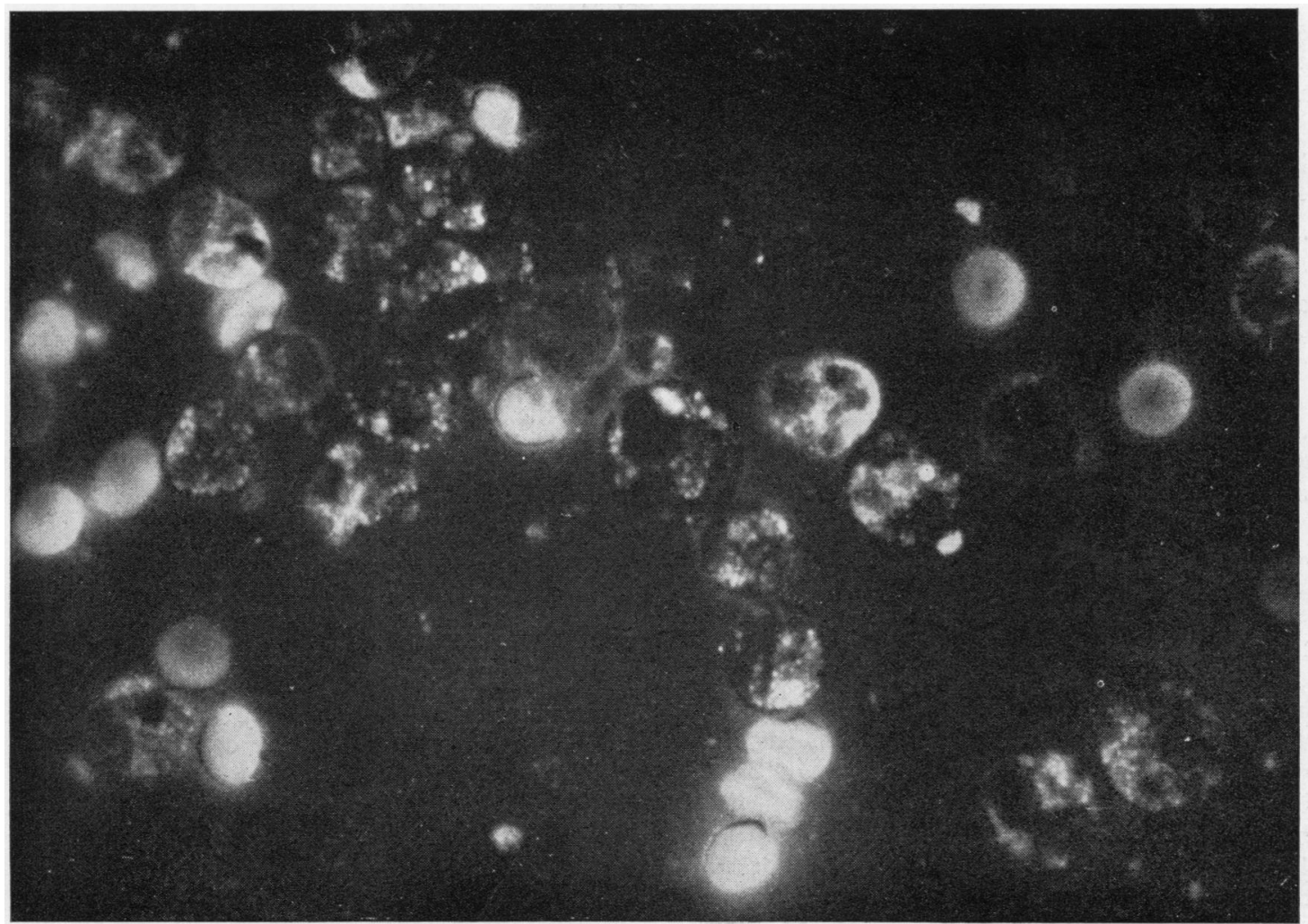

Fig. 8--Distribution of neutrophil cathepsin in a patient with rheumatoid arthritis. Note the various sizes of fluorescent granules. The centrally-located neutrophil exhibits a large phagosome (black) containing at its margin coalesced neutrophil granules (white) with their cathepsin. Several erythrocytes (brightly autofluorescent) appear in this field; such cells are rare in the synovial fluids collected for our study. $\times 1,132$.

Fibrin-related material was frequently in the same phagosome as IgM or IgG. In addition, the same neutrophil might also contain phagosomes showing only IgM or IgG. In some neutrophils all phagosomes contained a single constituent, i.e. IgM. Other neutrophils had yellow phagosomes indicative of combined IgM and IgG. Fibrin-laden neutrophils from RA patients frequently showed cathepsin with a fine granular distribution. In some cells pools of yellow indicated the intermixing of fibrinrelated material and cathepsin released from neutrophilic granules.

\section{Discussion}

Of considerable importance in appreciating the inflammatory dynamics of joint disease is the present demonstration of the immunochemical heterogeneity of the inclusion bodies of the exudative leucocytes. Even in RA it is unwise to assume the chemical nature of the leucocytic phagosomes (Willkens and Healey, 1966). By immunocytology with fluorescent markers for four different plasma proteins (fibrinogen, IgM, IgG and albumin), it became apparent that some phagosomes contained mixed aggregates. One prominent finding for most exudative neutrophils was the identification of fibrinrelated material either in large inclusion bodies or more finely dispersed throughout the cytoplasm. Frequently, a single neutrophil contained several proteins each in their separate intracellular compartments. One RA patient also exhibited phagosomes containing albumin or its immunological relatives. Cytoplasmic masses were especially conspicuous in synovial fluid neutrophils from RA patients with rheumatoid nodules. There was no obvious correlation between the synovial fluid differential rheumatoid agglutination titre and the presence of cytoplasmic masses. Confirmation was gained for the work of Rawson, Abelson, and Hollander (1965) that IgM and IgG were present in the exudative neutrophils of RA patients, but other types of protein also had intracellular localizations. The functional diversification of the synovial fluid leucocytes was 
well illustrated by our observation that the mononuclear population behaved differently from the exudative neutrophils.

Ultrastructural analysis of the exudative neutrophils by electron microscopy can be rewarding in illustrating the variety of intracellular inclusions (Riddle, Bluhm, and Barnhart, 1965; ZuckerFranklin, 1966). However, exact chemical identification of the constituents of the ingested material remains unknown without unique morphological features such as periodicity or the aid of immune markers to establish more precisely the immunological relationships. The latter method seems most reasonable for the study of proteins exposed to extravascular influences. Certainly the ultrastructure of fresh fibrin was markedly changed after implantation into inflammatory sites in dogs (Riddle and Barnhart, 1964). This partially-degraded fibrin was easily identified by immunofluoresence, although it did not possess the ultrastructural periodicity described as typical for fibrin. It seems likely that the proteins that accumulate in the synovial fluids in joint disease also may be altered or partially digested even before phagocytosis. The anticipated consequence of phagocytosis is intracellular digestion, so that functional phagosomes should contain altered protein. Immunological methods and especially immunofluorescence may offer the only practical indicator of the chemical nature of the cellular inclusions.

Two types of cytofluorescence (mass and diffuse) were encountered in synovial fluid leucocytes of our patient series. Large cytoplasmic masses were ordinarily limited to the RA leucocytes. Diffuse immunofluorescence appeared in exudative neutrophils regardless of clinical classification of the joint disease. Material ingested by neutrophils from RA patients was packaged in different ways even within the same cell. Light microscopy was inadequate to demonstrate that even the fine granular cytoplasmic staining, in fact, represented particulate materials which were membrane confined. Ultrathin sections and electron microscopy resolved these details (Riddle and others, 1965). A similar pattern of diffuse fluorescence was typical of our experience in dogs where inflammatory neutrophils had phagocytosed and digested fibrin (Riddle and Barnhart, 1964). It may be that this mechanism of handling phagocytosed material in small packages illustrates cell function compatible with a continued useful operation. In contrast, the massive inclusions observed in many RA neutrophils may signal the end of their useful service.

This communication extends the knowledge on the noncellular particulates present in the synovial exudates by chemical identification with immunofluorescence. Especially in RA patients, fibrinrelated masses or strands were easily found, as were aggregates of IgM and IgG with combined aggregates. The fibrin probably formed in vivo, as great care was taken in the joint aspiration and anticoagulant was added immediately. While rheumatoid factor activity had been reported in some joint exudates (Astorga and Bollet, 1965; Willkens and Healey, 1966), the presence of IgM-IgG aggregates has only been inferred until now. In addition, in some patients, strands of material reacted with fluorescent antialbumin and were most likely mucin, a mucopolysaccharide complexed with albumin (Pigman, Gramling, Platt, and Holley, 1959), or degraded mucin. Cell debris and shed cytoplasmic buds from exudative neutrophils were not prominent in the sedimentable portion of synovial fluids. The turbidity that remains after removal of leucocytes from the synovial fluid of the RA patients probably relates to the variety of protein aggregates and strands plus any cell remnants. Such particulates in synovial exudates must contribute to the persisting acute inflammatory state (Riddle and others, 1965).

Mechanisms that operate during inflammation are still poorly understood, even though much is known about cell participation and vascular events (Zweifazh, 1965). Phagocytosis by leucocytes provides one mechanism for defence. Vaughan (1965) has shown in vitro that leucocytes exercise some discrimination in what they phagocytose, with only the masrophages ingesting exhausted or dead autologous cells. Foreign particles were ingested by polymorphs and macrophages with equal effectiveness.

Selectivity in phagocytosis was clearly evident in our work with leucocytes from rheur atoid joints. Neutrophils and not mononuclears phagocytosed material immunologically related to fibrin or to IgM and IgG, or to albumin. Macrophages were seldom involved except occasionally to show phagocytosed cell remnants. The reasons for such leucocytic discrimination remain unknown as do the reasons for attraction of the various leucocytes into the joint.

Two different human protein aggregates (IgMIgG and fibrin) can be phagocytosed by normal leucocytes. However the handling of these proteins by exudative leucocytes in RA appears to be different.

Several investigators (Parker and Schmid, 1962; Astorga and Bollet, 1965; Zucker-Franklin, 1966) 
have shown in vitro that rheumatoid factor aggregates were phagocytosed by normal peripheral blood leucocytes. Zucker-Franklin reported that both neutrophils and monocytes avidly phagocytosed the aggregates. She described the specific immunofluorescence as diffuse. In contrast, both the work of Hollander's group and our own work on exudative neutrophils from RA patients frequently revealed focal fluorescence of phagosomes with IgM-IgG material in neutrophils almost exclusively. Thus the capabilities of the exudative leucocytes of patients with RA appear to be different from those of normal subjects.

Autologous fibrin, also, was phagocytosed readily by exudative neutrophils in experimental inflammatory sites in dogs (Riddle and Barnhart, 1964). In both dogs and humans enduring microthrombosis, there is strong circumstantial evidence for the neutrophilic phagocytosis from intravascular fibrin deposits (Barnhart, 1965). The immunofluorescence observed in these cases was most often diffuse. The specific cytofluorescence in dogs was clearly related to phagocytosis of fibrin aggregates per se and not to ingestion of the soluble circulating products of fibrinolysis (Barnhart and Cress, 1967). By immunofluorescence the cytoplasmic response occurred only in neutrophils and was diffuse. With exudative leucocytes from patients with RA both diffuse and localized fluorescence occurred.

Having established that leucocytes in vivo exercise their discrimination to phagocytose autologous protein aggregates, what is the evidence that leucocytes can be attracted in vivo to sites of such protein deposition? There are experiments to show that both fibrin and IgG can mobilize leucocytes under certain circumstances. Dumonde and Glynn (1962) showed that arthritis can be elicited in rabbits as an auto-immune reaction to fibrin. Lack (1964) applied this experimental design in goats and achieved an inflammatory response in the synovium. Also, heat-altered IgG induces synovitis when injected into clinically silent joints of RA patients by Restifo, Lussier, Rawson, Rockey, and Hollander (1965). Neutrophils were prominent in the joint exudates and were shown in the latter study to contain cytoplasmic inclusions. A conclusion of such work is that antigen-antibody complexes formed in vivo elicit the sequences of inflammation. However, neutrophil accumulation can be provoked by fibrin alone without the necessity of an immune basis.

The extravascular emigration of granulocytes can be encouraged by in vivo formation of fibrin or by autologous fibrin placed in experimental skin windows (Barnhart and Riddle, 1964; Riddle and
Barnhart, 1964). These granulocytes persist as the predominant cell type as long as fibrin is present. The attraction appears to be directly related to the presence of fibrin nets. Interpolation of a structured matrix (a graded porosity membrane) through which leucocytes can migrate did not result in neutrophil or other leucocyte accumulation on the other side of the membrane unless added fibrin was placed between the membrane and the collecting cover slip (Barnhart and Moore, 1966). Autologous fibrin nets have been placed under sterile conditions in skin windows of humans and the neutrophilic phase of inflammation can be prolonged as long as fibrin is added (Riddle, Bluhm, Barnhart, and Odle, 1967). Capillary permeability also can be increased in guineapigs by fibrinopeptides released from fibrinogen during the formation of fibrin (Copley, Hanig, Luchini, and Allen, 1966). It appears that fibrin formation is able to initiate and maintain the acute phase of inflammation.

The inflammatory exudates of our patients with RA were characterized by overt fibrin formed in vivo and appearing as extracellular strands and amorphous masses of material immunologically related to fibrin. In some cases, soluble fibrinogen according to biochemical assay and both intrinsic and extrinsic factors for accelerating fibrin formation existed in these synovial fluids (Bluhm, Riddle, and Barnhart, 1966). Thus, an environment favouring fibrin formation was the general experience rather than the exception in arthritis, regardless of subclassification. An attractive hypothesis is that fibrin related substances may be the components common to all types of inflammatory joint disease that provoke the acute inflammatory process. Whether or not fibrin formation in these joints occurred by the classical paths for blood coagulation, or as a result of adsorption, aggregation, or copolymerization with immune globulins, one effective stimulus for neutrophil emigration and accumulation has been identified.

Another prominent feature of many of the infiammatory exudates was the frequent degranulation of the neutrophils. Neutrophil granules are considered to be lysosomes which contain many hydrolytic enzymes (Hirsch and Cohn, 1964). For in tracellular digestion of phagocytosed protein to occur, the proteolytic enzyme group, cathepsin, must be concerned. Although cathepsin activity has been extracted from leucocytes (Štefanovič, Webb, and Lapresle, 1962; Astorga and Bollet, 1965; Barnhart and others, 1967), a direct cytochemical identification and localization in specific types of leucocytes has not been made until now. 
Our work with fluorescent anticathepsin was designed to answer the question whether or not RA neutrophils contained the enzymatic machinery (cathepsin) required for the intracellular digestion of protein. In the patients studied, blood neutrophils contained cathepsin with a pattern of distribution which appeared to be similar to the neutrophils' specific granulation. However, the exudative neutrophils of these same patients and others without companion blood neutrophils exhibited a very different type of cathepsin localization. Frequently RA neutrophils were clearly deficient in cathepsin; so the minimal staining reaction reflected either intracellular cathepsin utilization or extracellular release. It appeared that neutrophils emigrating from the vascular bed contained adequate stored cathepsin for intracellular digestion. However, with exposure to the enivronment of the rheumatoid joint, cathepsin was either released or not effective for digestion of the large protein masses. It may even be that certain types of protein structure are fairly resistant to proteolysis by cathepsin. Immunoglobulin was very resistant to digestion by cathepsin D (Barnhart and others, 1967).

Even though mononuclears appeared in the inflammatory exudates, cathepsin was not as prominent in these leucocytes, and the intracellular localizations were different from those observed in neutrophils. The typical reaction with fluorescent anticathepsin was a very fine cytoplasmic dust of low fluorescent intensity.

Mononuclear phagocytes apparently change both their morphology and their enzyme content in response to certain environments, according to Cohn and Benson (1965). Although acid phosphatase was most elevated, cathepsin activity also increased. It was suggested that an increase in lysosome number might be necessary for mononuclears to effectively dispose of inflammatory products and damaged tissue. In our inflammatory exudates there was no indication of increased cathepsin content within mononuclears (lymphocytes and hypertrophied lymphocytes) and even obvious macrophages did not contain much cathepsin. Such cells would appear poorly equipped to handle the protein particulates present in the synovial fluid. Further, the inflammatory exudate would not appear to be competent in provoking the mononuclear differentiation and adaptive enzyme synthesis required for them to serve as efficient phagocytes. It may well be that the typical neutrophil provides the first line of defence against protein particulates simply because it has on hand abundant and conveniently-packaged cathepsin.
In some exudates extracellular cathepsin was more evident than intracellular cathepsin. Biochemical assay of synovial fluids also revealed the presence of cathepsin (Bluhm and others, 1966). A certain amount of extracellular cathepsin may be beneficial in degrading some protein particulates in the exudate. Unrestricted proteolysis may have deleterious effects on the mucoprotein (a protective lubricant) to lead to permanent tissue damage. Some investigators have hypothesized that the release of lysosomal enzymes into the synovial fluid may be responsible for the persisting joint damage (Weissmann, Becher, Wiedermann, and Bernheimer, 1965). The present study provides evidence that one lysosomal enzyme, cathepsin $\mathrm{D}$, can exist in the synovial fluid and be correlated with decreased neutrophilic cathepsin.

\section{Summary}

The functional state of exudative leucocytes obtained from patients with inflammatory joint disease was evaluated with the aid of five immunofluorescent tools. Neutrophils were the predominant cell type in these exudates. Phagocytosis was prominent with material related to either albumin or fibrin usually widely distributed within the cytoplasm as fine granular inclusions. Neutrophils from patients with rheumatoid arthritis were frequently choked with massive intracellular inclusions which were identified immunologically as related to either IgG, IgM, or fibrin. Degranulation of these neutrophils was associated with reduction in intracellular cathepsin.

Protein particulates were abundant in many of the inflammatory exudates. Aggregates identified as IgG and IgM were limited to patients with rheumatoid arthritis. Strands and amorphous masses of fibrin as well as albumin-related materials were found in most exudates. Cathepsin was occasionally present as large extracellular particulates, but ordinarily as fine granules through the exudate.

Cathepsin was identified with an immunofluorescent marker. Neutrophils contained the greatest concentration of cathepsin and the distribution was either as small granules (similar in size to the specific neutrophil granules) or as large masses at the edge or in phagosomes. The blood neutrophils of patients with rheumatoid arthritis contained a good supply of cathepsin, although many of the synovial fluid neutrophils appeared deficient in cathepsin. Such deficiency, as well as finding extracellular cathepsin, confirmed cathepsin release from neutrophilic lysosomes in the course of inflammatory joint disease. 


\section{REFERENCES}

Anderson, F. G., and Barnhart, M. I. (1964). Amer. J. Physiol., 206, 929 (Prothrombin synthesis in the dog).

Astorga, G., and Bollet, A. J. (1965). Arthr. and Rheum., 8, 511 (Diagnostic specificity and possible pathogenetic significance of inclusions in synovial leucocytes).

Barnhart, M. I. (1965). Fed. Proc., 24, 846 (Importance of neutrophilic leukocytes in the resolution of fibrin).

—-, Anderson, G. F., and Baker, W. J. (1962). Thrombos. Diathes. haemorrh., 8, 21 (Immunochemical studies on proteins important in blood coagulation).

_ and Cress, D. C. (1967). Biochem. Pharm. (In press) (Plasma clearance of products of fibrinolysis).

- and Forman, W. B. (1964). In "Blood Coagulation, Hemorrhage and Thrombosis", ed. L. M. Tocantins and L. A. Kazal, p. 230. Grune and Stratton, New York.

and Moore, G. W. (1966). Unpublished observations.

—, Quintana, C., Lenon, H. L., Bluhm, G. B., and Riddle, J. M. (1966). Ann. N. Y. Acad. Sci. (In press) (Proteases in inflammation).

- - and Riddle, J. M. (1964). " "Proc. IX Europ. Congr. Hemat., Lisbon, 1963", p. 1,330. Karger, Basel.

Bluhm, G. B., Riddle, J. M., and Barnhart, M. I. (1966). Henry Ford Hosp. med. Bull., 14, 119 (Significance of fibrin and other particulates in rheumatoid joint inflammation).

Cohn, Z. A., and Benson, B. (1965). J. exp. Med., 121, 153 (The differentiation of mononuclear phagocytes).

Copley, A. L., Hanig, J. P., Luchini, B. W., and Allen, R. L., Jr. (1966). Fed. Proc., 25, 446 (Capillary permeability enhancing action of fibrinopeptides isolated during fibrin monomer formation).

Dumonde, D. C., and Glynn, L. E. (1962). Brit. J. exp. Path., 43, 373 (The production of arthritis in rabbits by an immunological reaction to fibrin).

Hirsch, J. G., and Cohn, Z. A. (1964). Fed. Proc., 23, 1023 (Digestive and autolytic functions of lysosomes in phagocytic cells).

Lack, C. H. (1964). Brit. med. Bull., 20, 217 (Proteolytic activity and connective tissue).

Lospalluto, J., and Ziff, M. (1959). J. exp. Med., 110, 169 (Chromatographic studies of the rheumatoid factor).

Mellors, R. C., Nowoslawski, A., and Korngold, L. (1961). Amer. J. Path., 39, 533 (Rheumatoid arthritis and the cellular origin of rheumatoid factors).

Parker, R. L., and Schmid, F. R. (1962). J. Immunol., 88, 519 (Phagocytosis of particulate complexes of $\gamma$-globulin and rheumatoid factor).

Pigman, W., Gramling, E., Platt, D., and Holley, H. L. (1959). Biochem. J., 71, 201 (Electrophoresis studies of human synovial mucin).

Rawson, A. J., Abelson, N. M., and Hollander, J. L. (1965). Ann. intern. Med., 62, 281 (Studies on the pathogenesis of rheumatoid joint inflammation. II. Intracytoplasmic particulate complexes in rheumatoid synovial fluids).

Restifo, R. A., Lussier, A. J., Rawson, A. J., Rockey, J. H., and Hollander, J. L. (1965). Ibid., 62 , 285 (Studies on the pathogenesis of rheumatoid joint inflammation. III. The experimental production of arthritis by the intra-articular injection of purified 7S gamma globulin).

Riddle, J. M., and Barnhart, M. I. (1964). Amer. J. Path., 45, 805 (Ultrastructural study of fibrin dissolution via emigrated polymorphonuclear neutrophils).

--, Bluhm, G. B., and Barnhart, M. I. (1965). J. reticuloendothel. Soc., 2, 420 (Interrelationships between fibrin, neutrophils and rheumatoid synovitis).

$-, \ldots,-$, and Odle, N. A. (1967). Thrombos. Diathes. haemorrh., (In press) (Leucocytefibrin interactions).

Solomon, A., Fahey, J. L., and Malmgren, R. A. (1963). Blood, 21, 403 (Immunohistologic localization of gamma-1-macroglobulins, beta-2A-myeloma proteins, $6.6 \mathrm{~S}$ gamma-myeloma proteins and Bence Jones proteins).

Stefanovič, J., Webb, T., and Lapresle, C. (1962). Ann. Inst. Pasteur, 103, 276 (Étude des cathepsins $\mathrm{D}$ et $\mathrm{E}$ dans des préparations de polynucléaires, de macrophages et de lymphocytes de lapin). 
Vaughan, R. B. (1965). Brit. J. exp. Path., 46, 82 (The comparative in vitro phagocytic activity of rabbit polymorphonuclear leucocytes and macrophages).

Weissmann, G., Becher, B., Wiedermann, G., and Bernheimer, A. W. (1965). Amer. J. Path., 46, 129 (Studies on lysosomes. VII. Acute and chronic arthritis produced by intra-articular injections of streptolysin $S$ in rabbits).

Willkens, R. F., and Healey, L. A., Jr. (1966). J. Lab. clin. Med., 68, 628 (The nonspecificity of synovial leukocyte inclusions).

Wintrobe, M. M. (1961). " "Clinical Hermatology", 5th ed., p. 410. Lea and Febiger, Philadelphia.

Wolman, M., and Behar, A. (1952). Exp. Cell Res., 3, 619 (A method of fixation for enzymecytochemistry and cytology).

Zucker-Franklin, D. (1966). Arthr. and Rheum., 9, 24 (The phagosomes in rheumatoid synovial fluid leukocytes: A light, fluorescence, and electron microscope study).

Zweifach, B. W. (1965). In "The Inflammatory Process", ed. B. W. Zweifach, L. Grant, and R. T. McCluskey, pp. 161-196. Academic Press, New York.

\section{L'immunocytologie des articulations arthritiques RÉSUMÉ}

On a évalué l'état fonctionnel des leucocytes des exsudats des sujets atteints de maladie articulaire inflammatoire à l'aide de cinq procédés d'immunofluorescence. Parmi les cellules de ces exsudats le neutrophiles prédominaient. La phagocytose était prononcée avec le matériel associé à l'albumine ou la fibrine, généralement repandues dans le cytoplasme sous forme de fines inclusions granulaires. Les neutrophiles des patients atteints d'arthrite rhumatismale étaient engorgés de massives inclusions intracellulaires, immunologiquement associées à l'IgG, l'IgM ou à la fibrine. La dégranulation de ces neutrophiles était associée à une réduction de la cathepsine intracellulaire.

Des particules protéiniques se trouvaient en abondance dans beaucoup d'exsudats inflammatoires. Des agrégations identifiées comme IgG et IgM se limitaient aux malades atteints d'arthrite rhumatismale. Dans la plupart des exsudats on voyait des brins et des masses amorphes de fibrine ainsi que du matériel lié à l'albumine. $\mathrm{La}$ cathepsine était quelquefois présente sous forme de grands amas de particules extracellulaires, mais généralement en guise de fins granules repandus dans l'exsudat.

La cathepsine fut identifiée au moyen d'un traceur immunofluorescent. Les neutrophiles en contenaient le plus, soit sous forme de petits granules (de la même taille que les granules neutrophiles spécifiques) soit en guise de fortes masses à la bordure ou dans les phagosomes. Les neutrophiles sanguins des malades atteints d'arthrite rhumatismale contenaient une bonne quantité de cathepsine, bien que beaucoup de neutrophiles du liquide synovial semblaient en manquer. Cette carence, ainsi que la présence extracellulaire de la cathepsine, confirment le fait que la cathepsine est libérée par les lysosomes neutrophiles au cours de la maladie articulaire inflammatoire.

\section{La inmunocitología de las articulaciones artríticas SUMARIO}

El estado funcional de los leucocitos exudativos en sujetos con enfermedad articular inflamatoria fué valorado con la ayuda de cinco instrumentos inmunofluorescentes. Entre las células de estos exudados el neutrófilo predominaba. La fagocitosis fué pronunciada con el material asociado con la albumina o la fibrina, generalmente extensamente distribuidas en el citoplasma en forma de finas inclusiones granulares. Los neutrófilos de enfermos con artritis reumatoide se observaron rellenos de inclusiones intracelulares macizas, asociadas inmunológicamente con la IgG, la IgM o la fibrina. La desgranulación de estos neutrófilos se asociaba con una reducción de la catepsina intracelular.

Los particulados de proteina se vieron en abundancia en muchos exudados inflamatorios. Agregados identificados como IgG e IgM se limitaron a enfermos con artritis reumatoide. En la mayoría de los exudados se vieron hebras y masas amorfas de fibrina así como de materiales relacionados a la albumina. La catepsina se encontraba a veces en forma de grandes masas extracelulares de particulados, pero ordinariamente en forma de finos granulos en el exudado.

La catepsina fué identificada por medio de un trazador inmunofluorescente. La mayor concentración de ella se encontró en los neutrófilos, en forma de pequeños gránulos (de tamaño similar al de los gránulos neutrófilos específicos) o de fuertes masas en el margen o dentro de los phagosomes. Los neutrófilos sanguíneos de enfermos con artritis reumatoide contuvieron buena cantidad de catepsina, pero muchos neutrófilos del líquido sinovial parecieron carecerla. Tal carencia, con el hallazgo de la catepsina extracelular, confirman la liberación de la catepsina de los lysosomes durante la enfermedad articular inflamatoria. 